\title{
The effect of ill-defined ferric oxides on the redox characteristics of flooded soils
}

\author{
N. van Breemen \\ Department of Regional Soil Science, Agricultural University, Wageningen, \\ the Netherlands
}

Received 20 March 1969

\begin{abstract}
Summary
Preliminary determinations of redox potential ( $\mathrm{Eh}$ ), $\mathrm{pH}$ and $\mathrm{Fe}^{2+}$ activity in the interstitial solution of two flooded soils indicate that the equilibria between ferric and ferrous iron are governed largely by ill-defined ferric oxides, which are intermediate between amorphous $\mathrm{Fe}(\mathrm{OH})_{3}$ and $\alpha-\mathrm{FeOOH}$ as far as stability is concerned. This partly explains the many unsuccessful attempts to interpret the Eh of flooded soils in terms of iron redox systems for which theoretical $E_{h}^{o}$ values can be calculated.
\end{abstract}

\section{Introduction}

Most Eh measurements in reduced media could be correlated with general characteristics such as the content of organic matter, the presence of large amounts of nitrate and manganese and the appearance of sulphate reduction (cf. Ponnamperuma, 1964; Starkey and Wight, 1946). Attempts to interpret these data in terms of several well established ferric-ferrous and manganic-manganous redox systems, were generally unsuccessful (cf. IRRI, 1964; Bohn, 1968). Important progress has been made by Ponnamperuma and others (IRRI, 1964 ; IRRI, 1965; Ponnamperuma et al., 1967). They performed Eh-pH measurements in a soil solution drawn by gravity through a sintered glass tube from a pot with water-saturated soil and transferred into a $\mathrm{N}_{2}$-filled cell, constructed for Eh-pH determination. In contrast to 'soil potentials', which often showed differences in the order of 100 to $300 \mathrm{mV}$, the 'solution $\mathrm{Eh}$ ' values were highly reproducible. They were positive throughout the inundation period and, in the last stages of reduction, were 100 to $300 \mathrm{mV}$ higher than the redox potentials measured in the soil. The results could be explained quantitatively by considering the equilibria between $\mathrm{Fe}^{2+}$ and the amorphous hydroxides $\mathrm{Fe}(\mathrm{OH})_{3}$ and $\mathrm{Fe}_{3}(\mathrm{OH})_{8}$. However, it is questionable whether the precautions to prevent oxydation by $\mathrm{O}_{2}$ were sufficient, particularly because oxygen can be absorbed on the surface of Pt-electrodes (Bohn, 1968).

\section{Experimental}

An alternative procedure for Eh- and $\mathrm{pH}$ determination in the soil solution has been made by placing two $15 \mathrm{~cm}^{3}$ porous pots (equipped with $\mathrm{Pt}$ and graphite electrodes, and a devise for collecting the soil solution by applying suction) in a 3-litre pot filled 
with water-saturated soil. Three Eh-electrodes were placed in the soil at the same depth as the porous pots. Periodically, Eh was measured after collecting 'fresh' soil solution in the porous pots by applying a pressure difference of 20 to $30 \mathrm{~cm} \mathrm{Hg}$. In the same way this (clear) solution was further transferred through a narrow plastic tube into a $30 \mathrm{~cm}^{3}$ beaker vessel (previously filled with $5 \mathrm{~cm}^{3}$ paraffine oil) for $\mathrm{pH}$ determination, $\mathrm{Fe}^{2+}$ analysis and measurement of the specific conductance to estimate the $\mathrm{Fe}^{2+}$ activitty coefficient (cf. Ponnamperuma, Tianco and Loy, 1966).

Besides the Eh-electrodes, a 52A Electrofact pH meter, a commercial glass electrode and a saturated calomel electrode were used for the Eh-pH measurements. The plastic tube was closed very tightly in between the measurements.

The soils used include an illitic clay soil from the Netherlands with $45 \%$ clay; $\mathrm{pH}_{\text {water }}=7.0 ; 0.47 \%$ organic $\mathrm{C} ; 0.86 \%$ 'free $\mathrm{Fe}$ ' and $0.06 \%$ 'free $\mathrm{Mn}$ ' (Soil 1 ) and one reddish brown soil from Kenya with $25 \%$ clay; $\mathrm{pH}_{\text {water }}=4.9 ; 1.84 \%$ organic $\mathrm{C}$; $2.18 \%$ 'free $\mathrm{Fe}$ ' and $0.08 \%$ 'free $\mathrm{Mn}^{\prime}$ ' (Soil 2). Soil 2 was enriched with $1 / 4_{4} \% \mathrm{CaCO}_{3}$ and, in one case, $1 / 2 \% \mathrm{C}$ as cellulose powder was added to Soil 1 to speed up reduction.

\section{Results and discussion}

The $\mathrm{pH}$ values of the soil solution were similar to those measured by means of a glass electrode pressed into the soil. This indicates that $\mathrm{CO}_{2}$ loss during transference of the solution was negligible.

After 20 to 50 days the 'solution Eh' and the 'soil Eh' reached values in the order of -100 to $-250 \mathrm{mV}$. The course of the 'solution Eh' did not show any irregularities during or after collection of the solution. This indicates that artificially induced oxidation did not influence the measured 'solution Eh'.

In all soils the $\mathrm{Fe}^{2+}$ concentration increased steadily throughout the inundation period. As this was likely to be the result of solution reduction of any form of ferric oxide, $\mathrm{Fe}_{2} \mathrm{O}_{3} . \mathrm{nH}_{2} \mathrm{O}$, this process probably can be represented by the reaction (neglecting the hydratation of the oxide):

$\mathrm{Fe}_{2} \mathrm{O}_{3}(\mathrm{~s})+6 \mathrm{H}^{+}+2 \mathrm{e} \underset{\mathrm{r}}{\longrightarrow} 2 \mathrm{Fe}^{2+}+3 \mathrm{H}_{2} \mathrm{O}$.

for which:

$\mathrm{Eh}=\mathrm{E}_{\mathrm{h}}^{\mathrm{o}}-0.059 \log \left[\mathrm{Fe}^{2+}\right]-0.177 \mathrm{pH}$

In Equation 1 the value of $\mathrm{E}_{\mathrm{h}}^{\circ}$ will depend on the form and hydratation of the ferric oxide.

Assuming that the measured $\mathrm{Eh}$ is determined by this equilibrium condition, the 'apparent $\mathrm{E}_{\mathrm{h}}^{\circ}$, can be calculated from the experimentally determined $\mathrm{Eh}, \mathrm{pH}$ and $\left[\mathrm{Fe}^{2+}\right]$. This 'apparent $\mathrm{E}_{\mathrm{h}}^{\circ}$ ' can be transformed into a standard free energy change of the reaction $\Delta F_{x}^{o}$, which can be used to estimate the 'apparent standard free energy of the formation' of ferric (hydr)oxide $\left(\triangle \mathrm{F}_{\mathrm{f} \mathrm{Fe}_{2} \mathrm{O}_{3}}^{\mathrm{O}}\right)$ participating in the reaction at a given time:

$\mathrm{E}_{\mathrm{h}}^{\circ}=\Delta \mathrm{F}_{\mathrm{r}}^{\circ} / 2 \times 23.06$

in which: 
$\triangle \mathrm{F}_{\mathrm{r}}^{\mathrm{o}}=\Delta \mathrm{F}_{\mathrm{f} \mathrm{Fe} \mathrm{e}_{2} \mathrm{O}_{3}}^{\mathrm{o}}-2 \triangle \mathrm{F}_{\mathrm{fFc}}^{\mathrm{o}} \mathrm{c}^{2+}-3 \triangle \mathrm{F}_{\mathrm{i} \mathrm{H}_{2} \mathrm{O}}^{\mathrm{O}}$

Substituting published values for $\triangle \mathrm{F}_{\mathrm{f} \mathrm{Fe}}^{\mathrm{o}}{ }^{2+}$ and $\triangle \mathrm{F}_{\mathrm{f} \mathrm{H}_{2} \mathrm{O}}^{\mathrm{O}}$ (Garrels and Christ, 1965) and combining Equations 1, 2 and 3 yield:

$\triangle \mathrm{F}_{\mathrm{f} \mathrm{Fe}_{2} \mathrm{O}_{3}}^{\circ}=46.12\left(\mathrm{Eh}+0.059 \log \mathrm{Fe}^{2+}+0.177 \mathrm{pH}\right)-210.7 \mathrm{kcal} / \mathrm{mole} \mathrm{Fe}_{2} \mathrm{O}_{3}$

The $\triangle F_{f}^{o}$ values have been calculated from Eh measurements, averaged for 'soil potentials' on the one hand and for 'solution potentials' on the other hand. The results have been plotted in Fig. 1, together with the $\triangle \mathrm{F}_{\mathrm{f}}^{\circ}$ values of the least stable (amorphous $\left.\mathrm{Fe}(\mathrm{OH})_{3}\right)$ and the most stable $(\alpha-\mathrm{FeOOH})$ ferric oxides (taken from Garrels and Christ (1965) and recalculated in terms of $\mathrm{kcal} / \mathrm{mole} \mathrm{Fe}_{2} \mathrm{O}_{3}$ ).

The actual $\triangle \mathrm{F}_{\mathrm{f}}^{o}$ values are not very reliable because the reproducibility of the $\mathrm{Eh}$ readings in each couple of porous pots was not better than 10 to $70 \mathrm{mV}$, corresponding to 0.5 and $3.2 \mathrm{kcal} / \mathrm{mole} \mathrm{Fe}_{2} \mathrm{O}_{3}$. Nevertheless the results allow some important conclusions.

The calculated $\triangle \mathrm{F}_{\mathrm{f}}^{\text {o }}$ generally shows a gradual decrease from values in the neighbourhood of $\triangle \mathrm{F}_{\mathrm{fe}\left(\mathrm{OH}_{3}\right)_{3}}^{\mathrm{o}}\left(-161.9 \mathrm{kcal} / \mathrm{mole} \mathrm{Fe}_{2} \mathrm{O}_{3}\right)$ at the start of the experiment, to values nearby $\triangle \mathrm{F}_{\mathrm{f}}^{\circ}{ }_{\text {a } \mathrm{FCOH}}\left(-177.3 \mathrm{kcal} / \mathrm{mole} \mathrm{Fe}_{2} \mathrm{O}_{3}\right)$ after 66 days. The 'solution Eh' obviously showed a better behaviour than the 'soil Eh'. Sometimes $\triangle \mathbf{F}_{\mathrm{f}}^{\text {o }}$ values calculated by means of the 'soil Eh' followed an irregular course (Soil 1 with cellulose), or were to low for any ferric oxide (Soil 1 with cellulose at 29 days and Soil 2 at 66 days).

The observations indicate the presence of ill-defined ferric oxides ('limonite') with $\triangle F_{f}^{o}$ values intermediate between $\triangle F_{\mathrm{f} F(\mathrm{OH})_{3}}^{o}$ and $\triangle F_{\mathrm{f} a-\mathrm{FeOOH}}^{\circ}$. The observed course is in accordance with thermodynamic principles, as the least stable ferric oxides will
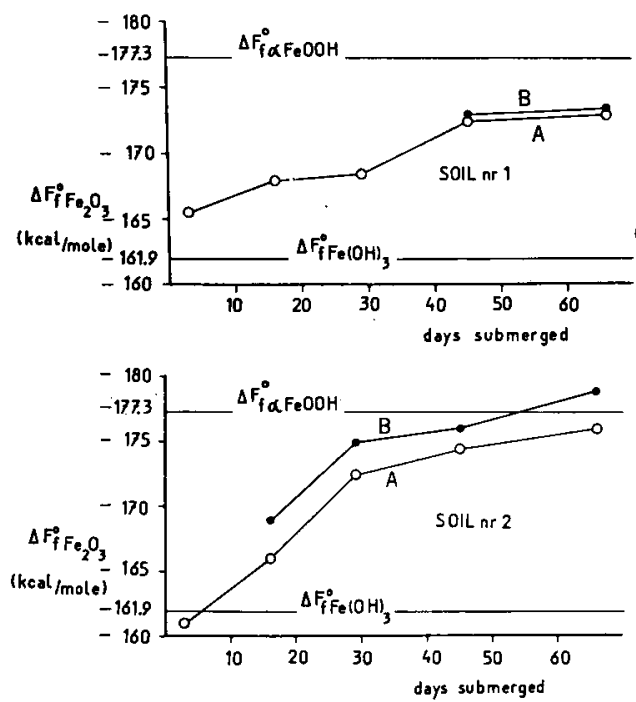

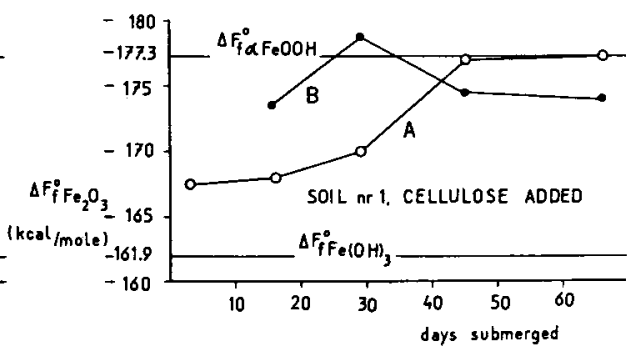

Fig. 1 Changes of $\triangle \mathrm{F}_{\mathrm{f}}^{\mathrm{O}} \mathrm{Fe}_{2} \mathrm{O}_{3}$, calculated from 'solution $E h^{\prime}(A)$ and 'soil $E h^{\prime}(B)$, with time 
determine the equilibrium in the first stages of reduction, while, after these compounds have been dissolved completely, the equilibrium will be shifted to involve oxides of higher stability. Addition of cellulose in Soil 1 induced a stronger reduction and consequently the calculated $\triangle F_{f}^{o}$ values were lower than those of the untreated soil. This indicates that single Eh-pH measurements are of little value in defining the iron redox system operating in flooded soils. Unless the Eh is determined by a well-defined ferric oxide, a check on the presence of a certain redox system is hardly feasible because the possible $\triangle F_{\mathrm{f}}^{\circ}$ range $\left(\triangle \mathrm{F}_{\mathrm{f} \mathrm{FeOOH}}^{\circ}-\triangle \mathrm{F}_{\mathrm{f}}^{\circ} \mathrm{Fc}(\mathrm{OH})_{3}=-15.4 \mathrm{kcal} / \mathrm{mole} \mathrm{Fe}_{2} \mathrm{O}_{3}\right)$ corresponds to an Eh variation of $330 \mathrm{mV}$. These observations may partly explain the many unsuccessful attempts to interpret in situ $\mathrm{Eh}$ measurements in terms of iron redox systems with well established $\mathrm{E}_{\mathrm{h}}^{\circ}$ values.

In addition it should be stressed that the approach discussed above could be adapted for a quantitative and qualitative analysis of ferric oxides in soils. Although such a method is probably very time-consuming, no other reliable procedure for the analyses of ill-defined ferric oxides appears to exist.

The difference between the results obtained by this method and the one used by Ponnamperuma et al. (1967) can be explained by considering the effect of very small $\mathrm{O}_{2}$ impurities in the $\mathrm{N}_{2}$ applied during collection of the solution. In the absence of a solid phase that participates in the redox reaction, the Eh can be changed easily by the oxidation of very small quantities of ferrous ions into ferric ions, because the ferric ion activity is extremely low under the redox conditions of flooded soils. For example, from the equation

$\mathrm{Eh}=1.19+0.059 \log \left[\mathrm{Fe}\left(\mathrm{OH}_{2}^{+}\right] /\left[\mathrm{Fe}^{2+}\right]-0.118 \mathrm{pH}\right.$

it can be calculated that $4 \times 10^{-10}$ mole $\mathrm{O}_{2}$ per litre can increase the Eh from -220 to $+80 \mathrm{mV}$ in a solution with a $\mathrm{pH}$ of 6.5 and a $\mathrm{Fe}^{2+}$ activity of $10^{-3}$ mole per litre. In a 'pure' $\mathrm{N}_{2}$ atmosphere it is almost impossible to maintain an $\mathrm{O}_{2}$ pressure small enough to prevent this oxidation. When the Eh has risen high enough to permit the oxidation and precipitation of $\mathrm{Fe}^{2+}$ to form either $\mathrm{Fe}(\mathrm{OH})_{3}$ or $\mathrm{Fe}_{3}(\mathrm{OH})_{8}$, the Eh depends on the $\mathrm{pH}$ and the $\mathrm{Fe}^{2+}$ activity as follows (Ponnamperuma et al., 1967):

$$
\begin{aligned}
& \mathrm{Eh}=1.06-0.059 \log \left[\mathrm{Fe}^{2+}\right]-0.177 \mathrm{pH}\left(\mathrm{Fe}^{2+}-\mathrm{Fe}(\mathrm{OH})_{3} \text { equilibrium }\right) \\
& \text { or } \\
& \mathrm{Eh}=1.37-0.089 \log \left[\mathrm{Fe}^{2+}\right]-0.236 \mathrm{pH}\left(\mathrm{Fe}^{2+}-\mathrm{Fe}_{3}(\mathrm{OH})_{8}\right. \text { equilibrium }
\end{aligned}
$$

In either case the $\mathrm{Eh}$ is fairly well buffered because a solid phase of unit activity participates in the reaction.

Equation 5 cannot be applied strictly to actual processes when the ferric ion activity is so small $\left(10^{-9}\right.$ to $10^{-13}$ mole per litre), but it probably indicates qualitatively the major source of the difference between the 'soil Eh' and the 'solution Eh', found by Ponnamperuma and co-workers. This consideration also explains why the Eh of a solution collected in a $\mathrm{N}_{2}$ atmosphere could be defined in terms of the $\mathrm{Fe}^{2+}-\mathrm{Fe}(\mathrm{OH})_{3}$ and $\mathrm{Fe}^{2+}-\mathrm{Fe}_{3}(\mathrm{OH})_{8}$ redox systems in a wide variety of soils.

\footnotetext{
1 This equation has been based on the assumption that $\mathrm{Fe}(\mathrm{OH})_{2}+$ is the predominant ferric ion species under the $\mathrm{pH}$ condition of flooded soils $(\mathrm{pH} 6-7)$. The $\mathrm{E}_{\mathrm{h}}^{\mathrm{o}}$ value of $1.19 \mathrm{~V}$ has been calculated from standard free energy values listed by Garrels and Christ (1965).
} 


\section{References}

Bohn, H. L., 1968. Electromotive force of inert electrodes in soil suspensions. Proc. Am. Soc. Soil Sci. 32: 211-215.

Garrels, R. M. \& Christ, C. L., 1965. Solutions, minerals and equilibria. Harper and Row + Weatherhill, New York-Tokyo; pp. 450.

IRRI, 1964. Annual Report International Rice Research Institute, Los Banos, Laguna, Philippines; p. 200-240.

IRRI, 1965. Annual Report International Rice Research Institute, Los Banos, Laguna, Philippines; p. 126-165.

Ponnamperuma, F. N., 1964. Dynamic aspects of flooded soils. In: The mineral nutrition of the rice plant, Proc. Symp. IRRI. John Hopkins Press, Baltimore USA. p. 295-328.

Ponnamperuma, F. N., Tianco, E. M. \& Loy, T. A., 1966. Ionic strengths of the solutions of flooded soils and other natural aqueous solutions from specific conductance. Soil Sci. 102: 408-413.

Ponnamperuma, F. N., Tianco, E. M. \& Loy, T. A., 1967. Redox equilibria in flooded soils: I. The iron hydroxide system. Soil Sci. 103: 374-382.

Starkey, R. L. \& Wight, K. M., 1946. Anaerobic corrosion of iron in soils. American Gas Association, New York, pp. 108. 